\title{
THE MAJOR CHALLENGES FACING ORGANISATIONS TO CREATE TECHNOLOGY-ENABLED VALUE IN THE FOURTH INDUSTRIAL REVOLUTION: A DYNAMIC CAPABILITIES PERSPECTIVE IN SOUTH AFRICA
}

\author{
J. Jacobs ${ }^{1 * \#} \&$ M.W.Pretorius ${ }^{1}$
}

\section{ARTICLE INFO}

\section{Article details}

Submitted by authors 28 Mar 2020 Accepted for publication 28 Jul 2020 Available online $\quad 31$ Aug 2020

\section{Contact details}

* Corresponding author jonatanjacobs@gmail.com

Author affiliations

1 Department of Engineering and Technology Management, Graduate School of Technology Management, University of Pretoria, South Africa

\# Author was enrolled for a PhD in the Department of Engineering and Technology Management, University of Pretoria, South Africa

\section{DOI}

http://dx.doi.org/10.7166/31-2-2345

\section{ABSTRACT}

Organisations are finding it increasingly difficult to create value in the current dynamic, globalised, interconnected, and ever more complex business and technology environments. The Fourth Industrial Revolution (FIR) is set to increase these challenges as a result of the increasing complexity and dynamic changes in market, societal, and technological trends. While current technological trends potentially offer great value to organisations, emerging technological implementations and transformations often fail to realise the desired value-creation outcomes. Following an exploratory study with qualitative interviews, it was determined that most of these challenges to technology-enabled valuecreation initiatives, in the current FIR related environment, can be linked to a dynamic capabilities perspective of strategic management. This perspective encompasses the enabling capabilities and strategic alignment between the external environment, an organisation's strategies, its strategy execution, and its capability creation, adaptation, and management.

\section{OPSOMMING}

Organisasies vind dit toenemend moeiliker om waarde te skep binne die huidige dinamiese, geglobaliseerde, geintegreerde en meer komplekse besigheids en tegnologiese omgewings. Die Vierdie Industriële Revolusie (VIR) vermeerder hierdie uitdagings as gevolg van die toenemende komplekse en dinamiese veranderinge in mark, sosiale en tegnologiese tendense. Terwyl huidige tegnologiese tendense groot waarde potensiaal bied vir organisasies, faal ontluikende tegnologie implementerings en transformasies om die verlangde waardeskeppingsuitkomste te lewer. Gevolglik, na 'n verkennende studie met kwalitatiewe onderhoude, is gevind dat die meerderheid van hierdie uitdagings tot tegnologie-gedrewe waardeskepping inisiatiewe in die VIR omgewing gekoppel kan word aan 'n dinamiese vermoë perspektief tot strategiese bestuur. Hierdie perspektief sluit in die vaardighede en die strategiese belyning tussen the eksterne omgewing, 'n organisasie se strategië, sy strategie uitvoering, asook sy vaardigheidskepping, aanpassing en bestuur.

\section{INTRODUCTION}

The industrial landscape is becoming more complex and dynamic [1], and both the business and the technology environments are changing at an ever-accelerating pace [2]. This pace, which is driven by the pace of innovation and change, is expected to increase further in the 21st century [3]. The result is that the future will present higher levels of uncertainty, discontinuity, and complexity [4], with increasingly borderless and dynamic environments [5]. These conditions pose various challenges to the value-creation initiatives of organisations, particularly when reinforced by disruptive technologies and innovations [6-9] and new industrial revolutions [10-11] that impact the capabilities required for value creation.

The business environment alone is characterised by highly globalised economies, which results in a high degree of interdependence [12] and competition between countries and organisations. Doing business becomes much more challenging due to the reinforced volatility of global economies and markets and 
shortened technology and innovation cycles. These and other trends, such as the increasing demand for individualised products and services, increase the complexity in value streams and value-creation systems [13-15]. Organisations are also increasingly expected to create more kinds of value for a broader range of stakeholders to take social trends into account. The value requirements from stakeholders and customers is thus becoming increasingly complex and multi-dimensional. This extends beyond the actual value offering, but also to how the value is designed, developed, produced, implemented, maintained, and decommissioned. Failing to address the set multi-dimensional requirements in an organisation's valuecreation system results in a high risk of exposure to negative consequences. This forces more innovation, a greater emphasis on how value is created, and a need to align value-creation efforts with external trends and requirements in order to address these challenges [16].

While the scale, dynamics, and complexity of the global marketplace is changing rapidly, so too are the magnitude and the speed of change in the technological environment [17]. These technological changes are often disruptive, particularly when an emerging technology surpasses the performance of a prior dominant technology design [18]. Such disruptive technologies ultimately change how an industry competes and brings strategic challenges and risks to organisations [6,8]. Disruptive technology typically introduces new competitive platforms, has the ability to initiate new markets, and changes organisations' technological competition status. This is generally achieved through the displacement of an incumbent technology or through the creation of a new capability where none had previously existed [9]. There is no organisation, industry, or government that is immune to the effects of technological disruption [19]. In fact, how an organisation uses advanced technology capabilities to create value and address external requirements has become the defining business challenge of our time [20].

When the impact of disruptive technological and innovative change is pronounced, the effects can manifest on multiple levels and lead to new eras in history. Such pronounced technological impacts, when rapid and profound changes occur that disturb the equilibrium, are known as industrial revolutions. Such a period often lasts for three or four decades, during which time technology (resources), manufacturing (processes), and employment (skills) change rapidly and in synchronicity. This makes industrial revolutions periods of profound change, because key innovations lead to new ways of doing things as new capabilities emerge, not just higher efficiencies or increased production at lower cost [11].

According to recent articles, books, conferences, presentations by technology entrepreneurs, and particularly policy reports issued by the World Economic Forum, a Fourth Industrial Revolution (FIR) has started $[10,21]$. Regardless of whether the present historical moment is characterised by sufficient levels of rapid and disruptive technological and innovative changes to constitute a new industrial revolution, this time has been characterised by a high degree of anxiety about current disruptive changes that bring strategic challenges to organisations $[22-23,11]$ and especially to their enabling capabilities.

Current technological developments, both revolutionary and evolutionary, are causing industries and sectors to appear, disappear, and change; and those that remain experience a blurring or even disappearance of boundaries [24-26]. A convergence of disciplines will further accelerate the disintegration of industry boundaries [10], such that all industries seem to move toward becoming technology industries. As more technologies and industries converge, the role of technology capabilities in value-creation systems is set to become more important and strategic. These do not necessarily have to result from radical technological innovations (nor from new entrants displacing incumbents) in order to be disruptive [24], as innovations that are disruptive may come from various sources. Such disruptions may change the constituent factors of capabilities, apart from technology resources, such as the underlying skills or processes or the business models that enable superior or novel value to be created and delivered by these capabilities [7]. The continual effort to account for these systemic impacts on value-creation systems can also be seen in various innovation management frameworks that build on the concept of innovation ecosystems to gain synergies between resources, people (skills), and processes by aligning with the broader external environment [105-108].

Figure 1 illustrates a system view of value creation in an organisation. In this view, an organisation is impacted by external requirements, and uses its capabilities (consisting of resources, people, and processes) to create value that is fed back to the environment. An organisation typically implements technology to create new value through a process of inputs, transformations, outputs, and feedback along the entire process [24]. It also involves the individuals, groups, and departments that form the organisation to enable its value-creation efforts, representing a basic input-process-output (IPO) function [27]. 


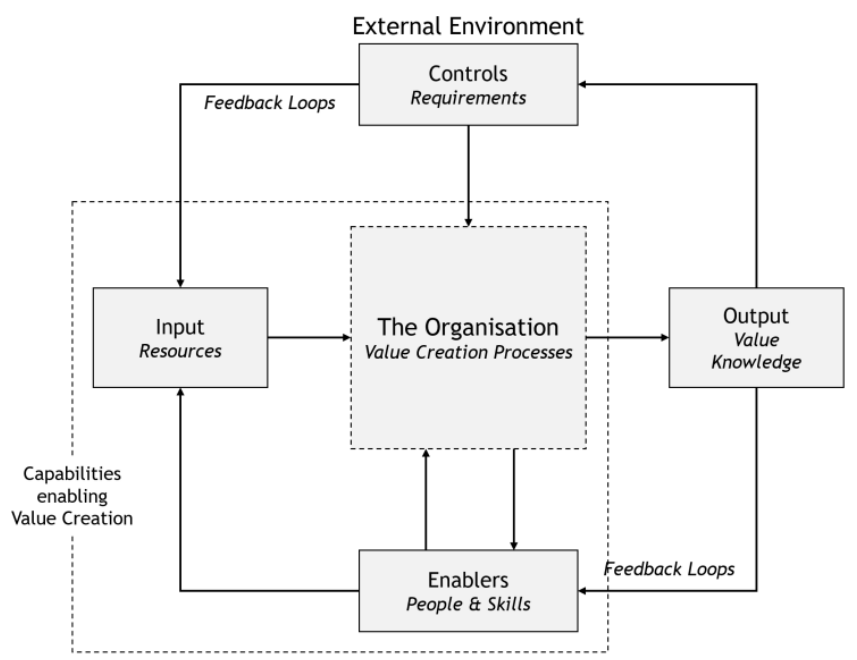

Figure 1: A systems view on value creation by an organisation, adapted [24,27]

The survival and the competitiveness of organisations increasingly depend on whether their value-creation systems' constituent capabilities are flexible, efficient, and adaptable [28], allowing them to supply customised value propositions both flexibly and fast and at the lowest cost possible [14,29]. This, in turn, needs to be driven by timely and dynamic adjustments in organisational and technology strategies to ensure that an alignment is achieved and maintained between the organisation's capabilities and the changes impacting its value-creation requirements [9].

The result is not only increased challenges to organisational and technological strategy development and execution [30], but also increased complexity in the strategic alignment of increasingly technologydependent value-creation capabilities. Furthermore, the innovation (i.e., new value-creation) systems in the FIR are increasingly likely to integrate across different scientific and technical disciplines [10-11]. This will require that many skill domains are incorporated into future value-creation capabilities [31]. Managers of organisations are faced with difficult decisions about how best to allocate limited resources in the face of the increasing cost, complexity, and risk of technology investments [3], and especially in terms of how to dynamically create and manage their capabilities to enable value creation in these dynamic business and technology environments [32-34].

These challenges are particularly hard to overcome for countries that face difficulty in developing and maintaining skills and capabilities [35-36], such as South Africa [37]. In order to validate these perceived challenges and to clearly define and articulate the core challenges that should be focused on, the following main research question was formulated: What are the major challenges that South African organisations face in their value-creation efforts, enabled by emerging technologies, in the FIR landscape?

This paper takes a dynamic capability-based view of technology-enabled value creation in the dynamic and complex environment currently referred to as the Fourth Industrial Revolution. The next section contains a literature overview in which 'value creation' is defined before the role of capabilities and strategic alignment in value-creation efforts is discussed. Section 3 presents the research model and research methodology followed for the qualitative data analysis of expert interviews. Section 4 presents the interview outcomes for this exploratory study, where the identified major challenges to value-creation initiatives in the FIR context are discussed. The paper closes with conclusions on the findings, before recommending future research.

\section{LITERATURE OVERVIEW}

\subsection{Introduction}

The literature overview provides the definitions and context for the study on value and value creation before providing the same for capabilities and strategic alignment along with the role they play in technology-enabled value-creation efforts. The capabilities discussion contains a specific focus on innovation and technology capabilities that are required in the FIR context, and on what constitutes a dynamic capabilities perspective in this context. The strategic alignment discussion presents a definition 
of the matter, and highlights a gap in the research before linking dynamic capabilities to strategic alignment as well.

\subsection{Value and value-creation}

'Value' is defined as a measure of worth that addresses a given need or organisational goal, in line with the measure of worth that a customer or stakeholder perceives or imposes on its value offering (product and/or service), operation, contribution, or other form of interaction related to the reason for its existence $[27,38-39]$.

It follows that 'value creation' can be defined as the act or process of creating value. This may, for example, be to achieve improved business performance such as increasing profits, making improvements in existing value offerings, creating new value offerings, reaching higher productivity, accessing new markets or industries, increasing efficiencies, lowering production costs, or increasing competitive advantage. Or it could be other desirable outcomes, from strategic organisational goals, such as improving safety, to increasing customer satisfaction, and improving community relationships or stakeholders' quality of life.

Value creation is followed by 'value capture', which can be defined as the realisation or capture of the desired value - e.g., receiving a financial return, an increase in share price, or improved stakeholder relations. The purpose of any organisation can then be summed up as the need to create and capture value to ensure its continued existence [30,39-40].

\subsection{Value-creation capabilities}

\subsubsection{Capabilities and their role in value creation}

A 'capability', in the simplest sense, implies "the ability to do something" [41], such as to make a decision or take an action toward achieving an objective. An 'ability', in turn, can be described as being constituted by the skills of a person as its basic building blocks [42]. Capabilities are also constituted by activities, which may be strategic or operational [41]. However, in order for the performance of an activity to constitute a capability, the capability must have reached some threshold level of practised or routine activity [43] - i.e., became embedded in processes. A capability can also be defined as a collection of routines that enable an organisation to perform some activity on a consistent (repeatable) basis [44], where 'routine' refers to a "repetitive pattern of activity" [43] - i.e., processes or procedures.

In the organisational context, capabilities relate to how an organisation can harness and organise the skills of people in the context of its available facilities, infrastructure, equipment, or tools through appropriate organisation in order to achieve certain objectives [42]. Inan and Bititci [43] refer to Helfat [45], who suggested that organisational capabilities allow organisations to create new products and processes and respond to changing market circumstances. They then refer to O'Regan and Ghobadian [46], who elaborate that an organisational capability is the ability to perform a coordinated task by using organisational resources, for the purpose of achieving a particular end result.

'Organisational capabilities' can then be defined as an organisation's capacity to deploy its tangible or intangible resources in order to perform a task or activity or improve performance [33] - i.e., to create some form of value. Amalgamating these discussed elements and structuring them in a framework yields the organisational capability framework shown in Figure 2. 


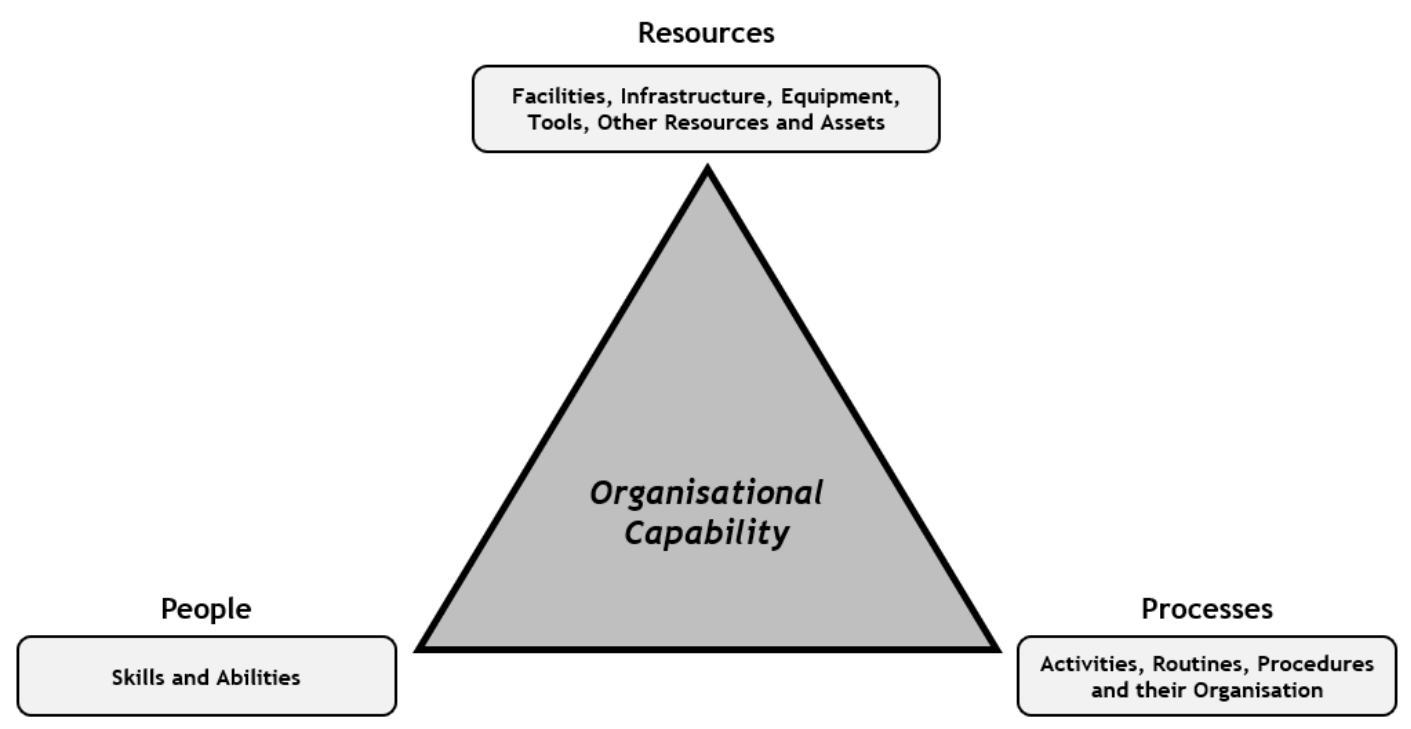

Figure 2: Organisational capability framework, adapted [33,41-44]

\subsubsection{Competencies, core competencies, and their relationship to capabilities}

Romanowska [42] refers to Davey [47], who defined 'competencies' as the combination of various capabilities that are linked through processes. Processes are therefore also an element that links various capabilities to achieve a specific purpose. Competencies describe how an organisation collectively integrates and manages its key capabilities, including the constituent resources and people (abilities and skills), through processes, to unlock some form of specialised expertise. This harmonious integration may include, for example, those capabilities necessary for managing the market interface, building and managing an effective infrastructure, and technology capabilities to create and capture value [18].

Schilling [18] agrees that capabilities contribute to a competency, and further defines a 'core competency' as the "harmonised combination of multiple resources and skills that distinguish an organisation in its marketplace". Schilling adds that core competencies distinguish an organisation strategically. Similarly, Prahalad and Hamel [48] define a core competency as the bundle of skills and technologies that enables a company to provide a particular perceived benefit (value) to customers, which cannot easily be imitated. Therefore core competencies draw on and integrate competencies and capabilities that are distributed across the organisation [42]. This includes and depends on the management of relationships and knowledge across different functions and business units, and often also across the supply chain [18].

Javidan [49] provided a framework for the hierarchy of how organisational resources, capabilities, competencies, and core competencies relate to one another. This framework, shown in Figure 3, also indicates how value increases higher up the hierarchy, along with the difficulty of obtaining each level in the hierarchy.

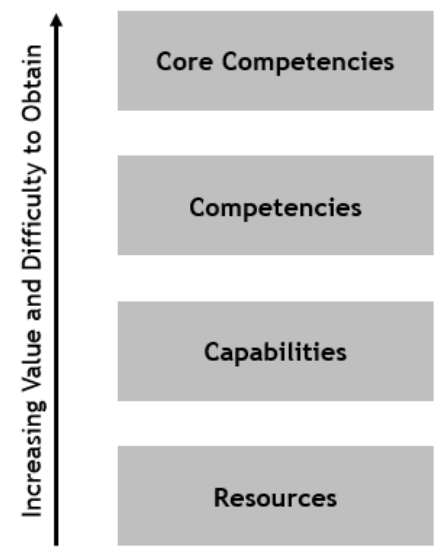

Figure 3: Competencies hierarchy framework, adapted [49] 
It follows that capabilities can also be defined as the means or ability to create value, whereas competencies may be defined as unique capabilities that may be leveraged to create unique and difficultto-imitate value; and core competencies are those competencies that form the core of an organisation's competitiveness in its value-creation system and that affect its sustainability. It is therefore preferable to develop competencies and core competencies from capabilities in competitive environments. However, since capabilities form the foundation of value creation (however distinctive) across different types of organisation, they are proposed as the unit of analysis, particularly since capabilities also provide the means to adapt to changing circumstances, while competencies may 'lock' organisations into certain path dependencies (where the organisation can go).

\subsubsection{Innovation, innovation capability, and its role in enabling value creation}

Christensen [50] defines 'innovation' as a “change process by which an organisation transforms labour, capital, materials, or information into products and services of greater value". This definition indicates that capabilities realise value through a process of change - i.e., innovation is not part of the ordinary. Innovation can also be defined as doing something new (i.e., a product, process, or service) that is of value. This newness in value is not limited to the world or market, and can include newness to an organisation [51].

Schilling [18] defines innovation more broadly as "the practical implementation of an idea into a new device or process". White and Bruton [24] state that innovation is simply defined by some as "invention plus exploitation". However, they themselves believe innovation is more encompassing, and also includes the process of developing and implementing the invention. These authors [24] refer to the definition of Rubenstein, where innovation is "the process whereby new and improved products, processes, materials, and services are developed and transferred to a plant and/or market where they are appropriate". There can thus be newness of the product or process, newness of the usage, or a combination of both.

From this, innovation is defined as the process whereby new value is created and captured. 'Innovation capability' can then be simply defined as the capability to innovate, where innovation capability enables the resulting innovation, which leads to the desired new value creation for the organisation. Innovation capability is necessary in order to create new value in response to the dynamic challenges and processes of change faced by organisations. These changes and challenges may result from changing requirements and impacts from customers, stakeholders, and competitors, and require different responses. Therefore, innovation capability enables the pursuit of ever-changing strategies to ensure the survival and growth of the organisation in its dynamic environment, by adapting the organisation's value offering and how it is created, in order to maintain its alignment with its environment.

\subsubsection{Technology, technology capability, and its role in enabling value creation}

Burgelman, Maidique \& Wheelwright [52] defined technology by saying that "technology refers to theoretical and practical knowledge, skills and artefacts that can be used to develop products and services as well as their production and delivery systems". Technology can be embodied in "people, materials, cognitive and physical processes, plants, equipment, and tools".

White and Bruton [24] defined technology as "the practical implementation of learning and knowledge by individuals and organisations to aid human endeavour. Technology is the knowledge, products, processes, tools, and systems used in the creation of goods or in the provision of services". Or, in the context of this paper, the latter part can simply be replaced with '...used in the creation of value'. This definition has a strong systems view of what 'technology' is and does.

Various definitions imply that there is a process involved in technology, that change is an outcome of technology, and that technology involves a systematic approach to delivering the desired outcomes (improvements, objectives, and outputs) - i.e., value [24]. Technology is also described as an enabler to satisfy market needs [53] and as a key driver of innovation and sustainable business growth [3]. In fact, technological innovation has become the most prominent driver and enabler of improved competitiveness in response to competitive challenges $[18,54]$.

Technology plays a significant role in (and is a major source of) productivity, innovations, business model development, economic growth, and wealth generation in the socio-economic environment in various valuecreation systems $[30,53]$. Technology can be seen as the enabler and key driver of value creation in the context of enabling innovation (exploring new possibilities), exploiting existing certainties (capabilities and competencies), or addressing specific challenges (shifting stakeholder requirements, or new business objectives for improved operational excellence, increased revenue, reduced costs, improved efficiency, 
etc.) $[3,30,53,55]$. This may be interpreted to mean that technology and technological innovation exist to add value to an organisation and/or to society [24].

However, more than technology enablers (e.g., components, equipment, hardware, or software) is necessary to create value. What organisations need is the 'technology capability' to address their needs in line with their value-creation initiatives [43]. Considering the definitions of a capability, a 'technology capability' can be defined as the ability to do something through technology (e.g., making decisions or taking actions, enabled by technology, to achieve an objective). This may include or overlap with innovation capability, where the focus is on technological innovation or creating some new value enabled by technology.

Technology capability constitutes more than the physical or digital technological resource. It also contains the knowledge (know-why, know-what, know-how) of an organisation to support its reason for existing, which relates to both the science and engineering aspects and to the process and management aspects [5658]. This technological knowledge comprises both explicit (i.e., artefacts such as tools, procedures, and guidelines) and tacit (such as abilities, training, and experience) knowledge [3]. Technology capability also consists of the people and their skills that realise the technology capability when they bring the necessary technological resources and knowledge aspects together [58].

The elements that constitute technology capability, as a result of a systemic output as outlined above, are shown in Figure 4 in the form of a technology capability framework. This framework contains the same elements as those in the organisational capability framework in Figure 2, but includes elements specific to technology capability. The result resembles and relates to the often-cited people-process-technology framework, although it was developed from a capability perspective.

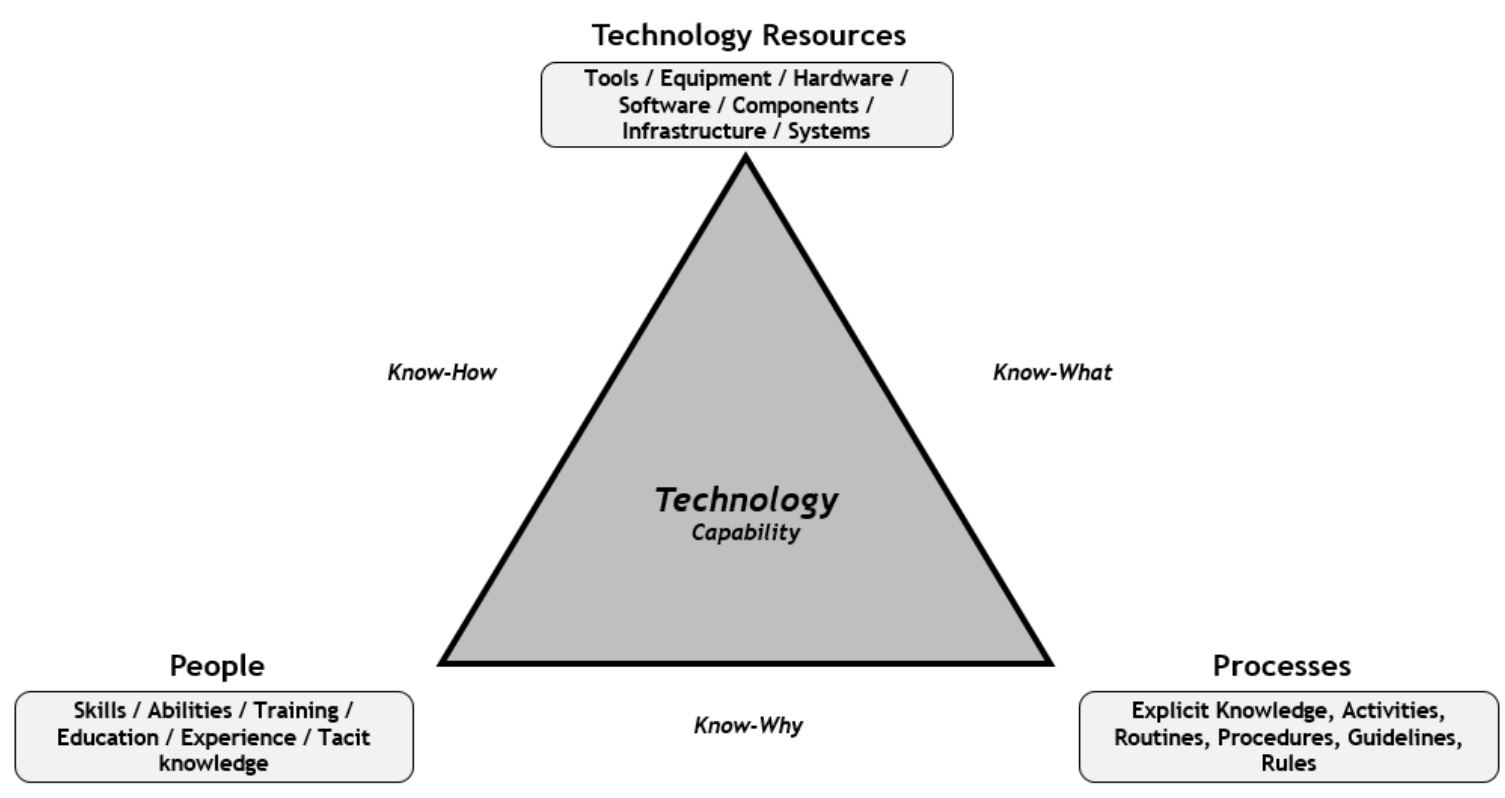

Figure 4: Technology capability framework, adapted [24,43,52,58,59]

\subsubsection{Dynamic capabilities and their role in enabling value creation}

The concept that capabilities influence strategy and thus value-creation initiatives can be dated back to Andrews [60]. However, according to Pisano [34], attempts to formalise a 'capabilities-based' approach to strategic management stemmed from the work of Teece and Pisano [61], Teece et al. [32], and Eisenhardt and Martin [62] on 'dynamic capabilities'.

Teece et al. [32] defined dynamic capabilities as the organisation's "ability to integrate, build, and reconfigure internal and external competences to address rapidly changing environments". Considering the definitions given on capabilities and competencies, the word 'competencies' from the above definition could perhaps be replaced with 'abilities'. As Teece et al. [32] also stated, dynamic capabilities "reflect an organisation's ability to achieve new and innovative forms of competitive advantage given path dependencies and market positions". 
'Dynamic capabilities' refers to a way to dynamically create, adapt, and manage capabilities in line with, or in response to, dynamic strategic and external requirements (e.g., from market, business, and technology environments, or from internal strategies) [32-33]. Since organisations are especially challenged to revise their routines of activities when the environment is dynamic [33], a dynamic approach to adaptation is becoming increasingly important in the current FIR landscape.

Eisenhardt and Martin [62] proposed a view that focused on specific organisational processes that integrate, reconfigure, gain, and release resources to achieve new resource configurations. Helfat et al. [63] later noted that scholars of dynamic capabilities defined dynamic capability in more general terms as "the capacity of an organisation to purposefully create, extend, and modify its resource base". Teece $[8,41]$ suggested that dynamic capabilities could be disaggregated into three broad capacities - sensing, seizing, and transforming - which together form a dynamic capabilities framework (DCF).

Inan and Bititci [33] described operating capabilities as those organisational capabilities that enable the organisation to execute its main operating activities on an on-going basis. Dynamic capabilities are then described as the ability of an organisation to reconfigure its operating capabilities in an attempt to adapt and evolve the organisation. They are the organisational and strategic routines that enable organisations to achieve new resource configurations as markets emerge, collide, split, evolve, and die. They are thus change-oriented capabilities that help to redeploy and reconfigure the resource base to meet changing customer and stakeholder requirements and competitor strategies [33].

Essentially, Teece's concept of dynamic capabilities states that what matters for business is corporate agility, which is the capacity to (1) sense and shape opportunities and threats, (2) seize opportunities, and (3) maintain competitiveness through enhancing, combining, protecting, and, when necessary, reconfiguring the organisation's intangible and tangible assets/resources [32,64].

Despite a significant body of literature on the topic, Pisano [34] points out that there is a lack of a common understanding of what dynamic capabilities are, what they mean for strategy, and how an organisation can manage them coherently. Therefore, dynamic capabilities are understood and defined here as the ability to dynamically create, adapt, and manage capabilities in response to dynamic challenges imposed on the organisation for the value that it should create and offer. This is essentially a strategic management approach that aims to maintain the alignment between the external environmental and market requirements, the organisation's strategies, its value creation in order to realise the strategies, and the capabilities required to realise the value creation. Such an approach is embedded in the key activities of the strategic management process (shown in Figure 5), which include [24,65]:

- $\quad$ Formulating/developing organisational strategy and planning (or strategic planning);

- Implementing/executing organisational strategy; and

- $\quad$ Exercising evaluation (or monitoring) and control.

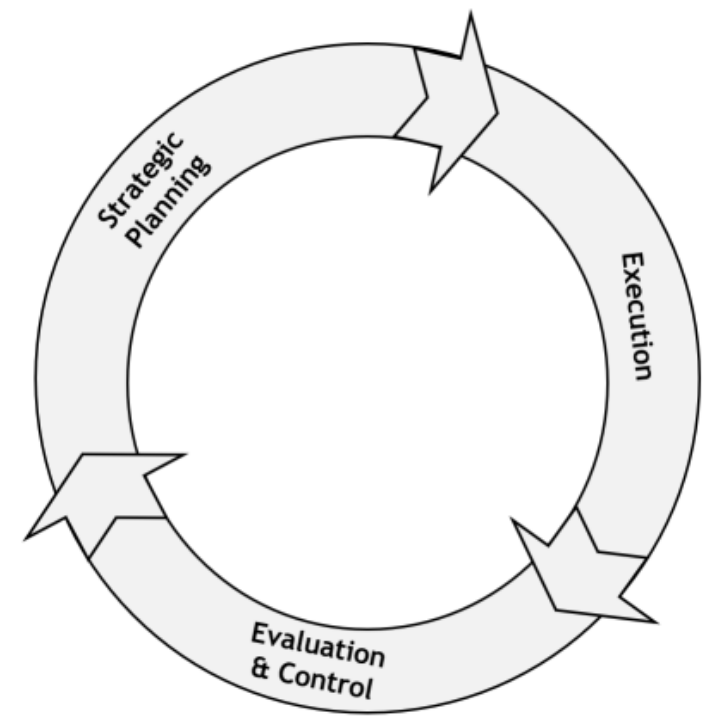

Figure 5: Key activities in the strategic management process, adapted $[24,65]$ 


\subsection{Strategic alignment and the impact on value creation}

\subsubsection{Strategic alignment}

'Strategic alignment' is described as applying information technology (IT) "in an appropriate and timely way and in harmony with business strategies" [66]; or as "the degree to which the IT mission, objectives, and plans support and are supported by the business mission, objectives, and plans" [67]; or simply as "using IT in a way consistent with the firm's overall strategy" [68].

A lack of alignment between business and IT strategies has been noted among the key challenges that cause IT investments and implementations to fail [69-70]. In fact, a failure to align organisational and IT strategies strategically may lead to significant opportunity and financial costs [71]. Misalignment can also cause internal tension [72] and a disconnect between an organisation's strategy and its operating model, resulting in confusion and a negative impact on value-creation efforts [73]. Historical imbalances between technology 'push' and market 'pull' have even resulted in business failure [74]. According to McKinsey \& Company [20], alignment remains a persistent struggle for organisations. Among the current digital strategy transformation trends, there are examples of enterprise-wide transformations that 'come up short' simply because leaders have a difficult time creating coherent strategies that stitch together their digital priorities with other major business objectives.

Similarly, information systems (IS) research and practice on improved strategic alignment between IT and business (on various organisational levels) has been shown to impact performance positively [75-77], which may lead to improved value creation, such as improved efficiencies, reduced costs, improved customer and/or supplier relationships, and the ability to create new products or solutions [78]. Strategic alignment has also been argued to be a source of competitive advantage [79].

The literature on strategic alignment focuses on the alignment of IT strategies with business/organisational strategies [72,79-81], as has been the case for the past two decades [81]. The collective term 'organisational strategy' will be used to account for a single strategy, or for various combinations of corporate, business, and functional strategies, where the sub-division of an organisation's strategy into multiple strategies typically depends on its size and complexity [82].

It can be argued that the focus on IT reveals a gap in the literature on strategic alignment in the FIR, since the FIR consists of digital, physical, and biological technology spheres [10]. Even in the Industry 4.0 context, as the cyber-physical (IT and operational technology (OT)) integration of two of these spheres [83-84], the literature is lacking, or at least primarily focused on the IT/digital sphere - i.e., on data and their computation as part of the continued extension of the Third Industrial Revolution [11].

With increasingly dynamic business and technology environments in the FIR, alignment may prove even more challenging in future. Organisations undergo and face a great deal of faster and more frequent change, while their operating and strategic models are also adapted more frequently [85]. Organisations also have increasingly digitised or digitalised their operations and processes [86-87]. This too has notable implications for alignment [85-86]. For technology implementations and transformations to yield meaningful value in this environment, strategic alignment is necessary between each of a value-creation system's hierarchies, as discussed in Table 1.

Table 1: Strategic alignment between a value-creation system's hierarchies

\begin{tabular}{|l|l|}
\hline Alignment between: & References \\
\hline $\begin{array}{l}\text { The external environment and market and the development of the } \\
\text { organisational strategy. }\end{array}$ & {$[18,24,30,53,65,88]$} \\
\hline The organisational strategy and the technology strategy. & {$[24,52,89-90]$} \\
\hline $\begin{array}{l}\text { The developed and tightly knitted strategies and the strategy execution, } \\
\text { implementation, or operational activities. }\end{array}$ & {$[24,53,69]$} \\
\hline $\begin{array}{l}\text { The strategy execution or operations (i.e., the value-creation level) and the } \\
\text { enabling technology capabilities, such as processes, skills development, } \\
\text { infrastructure, and other resources. }\end{array}$ & {$[69-70,91-93]$} \\
\hline
\end{tabular}

From Table 1, 'strategic alignment' is defined here as the process of continually and strategically aligning (1) an organisation's external environment and its organisational strategy, (2) its organisational strategy and technology strategy, (3) its aligned strategies and its strategy execution, and (4) its strategy execution and the enabling value-creation capabilities. Figure 6 is an illustration of strategic alignment in the context of an organisation's value-creation system, as shown in Figure 1. Figure 6 contains multiple hierarchies, consistent with a systems view (and technology roadmapping), feedback loops representing the alignment 
processes, and process flows in the form of a 'flow diagram' that represents the flow of events for valuecreation initiatives. Figure 6 also illustrates how the system hierarchies may consist of multiple sub-layers or variations for each of the primary hierarchies that need to be accounted for in each specific context.

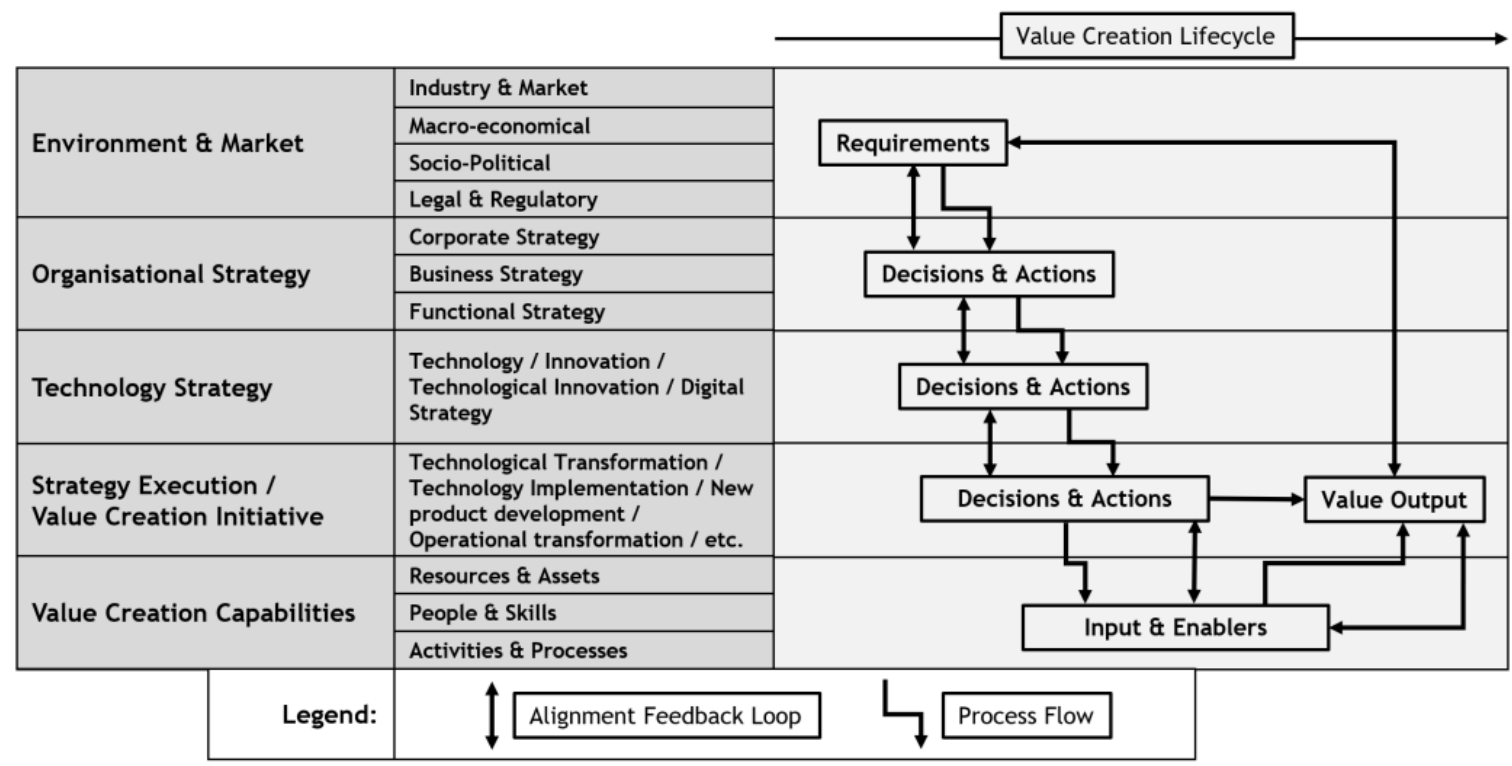

Figure 6: A representation of strategic alignment in an organisation's value-creation system

Alignment with the external environment may include the fit between the organisation's strategies and the macroeconomic, social, political, technological, environmental, legal, market, and other factors and trends impacting the organisation. It has been noted that organisations struggle, in general, to adapt to new trends, especially social and technological trends, and to optimise their investment processes and strategic decisions in line with new opportunities or threats in the environment $[30,53,88]$.

On the strategy development level, the increased prominence of technology in value creation, competitiveness, survival, and addressing environmental requirements largely drives the need for the increased integration (alignment) of technology and organisational strategies [24,89]. Strategic alignment here supports effective communication and coordination of strategy execution, particularly through systematic technology management activities over the product (or the value-creation) life-cycle [90]. Therefore, during strategy development, it is necessary to consider the technology aspects that constitute the company's value system [94]. Alternatively, the technology strategy has to be derived from the business/organisational strategy in support of (i.e., aligned with) its needs $[52,95]$.

On the strategy execution level, continual alignment between the strategy formulation process and the execution levels is necessary to ensure that outcomes match objectives and goals [53]. Furthermore, the relationship between technological capabilities and strategic objectives is increasingly important, since decisions that do not incorporate technological capability considerations for the creation of new value are unsustainable [93]. Value creation (particularly through innovation) also requires the alignment of priorities between all of the functions (and interest groups) responsible for successfully creating the desired value [74]. The ability to create, modify, and maintain this alignment - while business and other conditions change, new opportunities arise, and new capabilities are developed - can mean the difference between capturing the benefits of being a market leader and being a market follower [91].

\subsubsection{Dynamic capabilities and the link to strategic alignment}

Strategic alignment is a moving target, and executives continually evaluate market trends, competitors, and new innovations in order to stay competitive. This generates fluidity in the organisation's strategy, which makes alignment more difficult [96]. And with technology also continually changing [3,17], it is increasingly difficult for strategies and capabilities to remain aligned $[24,66]$.

A shift of focus from alignment as an end-state or fixed goal to the aligning process itself has provided a useful perspective [97-98]. This has spurred suggestions of maintaining dynamic synchronisation between strategies and other functions, as suggested by Mithas, Tafti and Mitchell [99]. Since strategy has been noted as being implemented via a series of processes that occur over time [92], this suggests that strategic 
alignment forms a continual part of strategy execution. This perspective places a stronger emphasis on the monitoring and control activities in strategic management as a way to maintain strategic alignment [65].

A dynamic synchronisation (or dynamic alignment) perspective is also supported when considering the findings from McKinsey \& Company that executives are more likely to adopt a 'rolling strategy' in the current environment, as opposed to traditional three- to five-year strategies [73]. Alignment is, therefore, a continual process of aligning with the moving target of emerging strategy. And aligned strategies (such as digital strategies) are inherently multi-functional [86]. This requires alignment between, and even the simultaneous development and reconfiguration of, IT (or other technological) and business resources across multiple organisational processes [72].

A dynamic alignment approach is also supported by the argument from various researchers that planned action alone does not lead to successful strategic alignment. To align with a shifting goalpost, both intended (planned) and emergent aligning actions are required during the aligning process in order to pursue planned changes and to manage emerging issues [72,97-100]. This explains why studies have begun to link alignment with the organisation's ability to sense and respond to dynamic changes [100], as opposed to simply seeing the strategic value of alignment as how the state of alignment influences organisational performance.

Baker, Jones, Cao \& Song [79] suggested that strategic alignment can be conceptualised as a management capability, where such a capability fits the description of dynamic capabilities from the DCF perspective on strategic management [32,79]. Similarly, Yeow, Soh \& Hansen [72] conducted a five-year longitudinal study on applying a dynamic capabilities approach to alignment. Their study showed a close link between organisational capabilities and alignment, and that alignment is brought about through the sensing, seizing, and transforming capacities (i.e., the dynamic capacities) of the DCF and its associated aligning actions. This is congruent with the dynamic capabilities strategic management view, in which strategy is seen as being tightly linked to the three dynamic capacities of the DCF [41].

Yeow et al. [72] conceptualise dynamic capabilities as being composed of both broad organisational capacities (i.e., sensing, seizing, and transforming) and specific decisions and actions that work together to effect organisational change as part of each capacity. For example, the sensing capacity consists of scanning, learning, and calibrating activities involved in the identification, development, co-development, and assessment of technological opportunities in relationship to (i.e., aligned with) customer needs [41], as well as sensing environmental changes and/or internal decisions [72].

The seizing capacity consists of designing, selecting, and committing activities, such that the organisation mobilises resources to address the needs and opportunities identified by the sensing capacity in order to capture value. Seizing plays a critical role in the alignment between identified opportunities in the external environment and actions to create value from it. The seizing capacity is also involved in the decision-making about what specific changes to make across and in the organisational system (its activities and processes), in order to create and capture the desired value $[8,41,72]$.

The transforming capacity consists of leveraging, creating, accessing, and realising activities to enable continual renewal in the modification and alignment, co-alignment, realignment, and redeployment of assets, resources, processes, and/or organisational functions [8,72,101]. The transforming dynamic capacity enables the reconfiguration of existing resources to align them with the new strategy. Creating or acquiring new resources or complete capabilities through this capacity also enables alignment with both existing gaps and future strategic goals. This provides a useful way to examine and enact the aligning process, since it focuses on the actions taken by organisations to change their capabilities (i.e., resources and assets, people and skills, activities and processes) to adapt to dynamically changing environments [72].

\subsection{Summary of the literature contribution}

In summary, the literature overview has defined 'value creation' as the pursuit of realising value by addressing a need or achieving a goal. Creating and capturing value is the purpose of an organisation, and doing so requires capabilities that are on a high level of analysis constituted by resources and assets, people and skills, and activities and processes. In the FIR environment, technology and innovation capabilities play a particularly important role, since new value-creation approaches or outcomes are often required to address dynamic requirements from internal and external changes, and technology is the primary enabler of value-creation initiatives. Furthermore, the dynamic capabilities perspective on the strategic management of such technology-enabled value-creation efforts was shown to enable both the valuecreation capabilities and the strategic alignment required to dynamically adapt an organisation's value- 
creation system to its dynamic environment. These literature outcomes shape the hypotheses and the research design and method to test these hypotheses, as discussed in the next section.

\section{RESEARCH METHODOLOGY}

\subsection{Conceptual research model}

The conceptual research model is shown in Figure 7, with the hypotheses stated in Table 2.

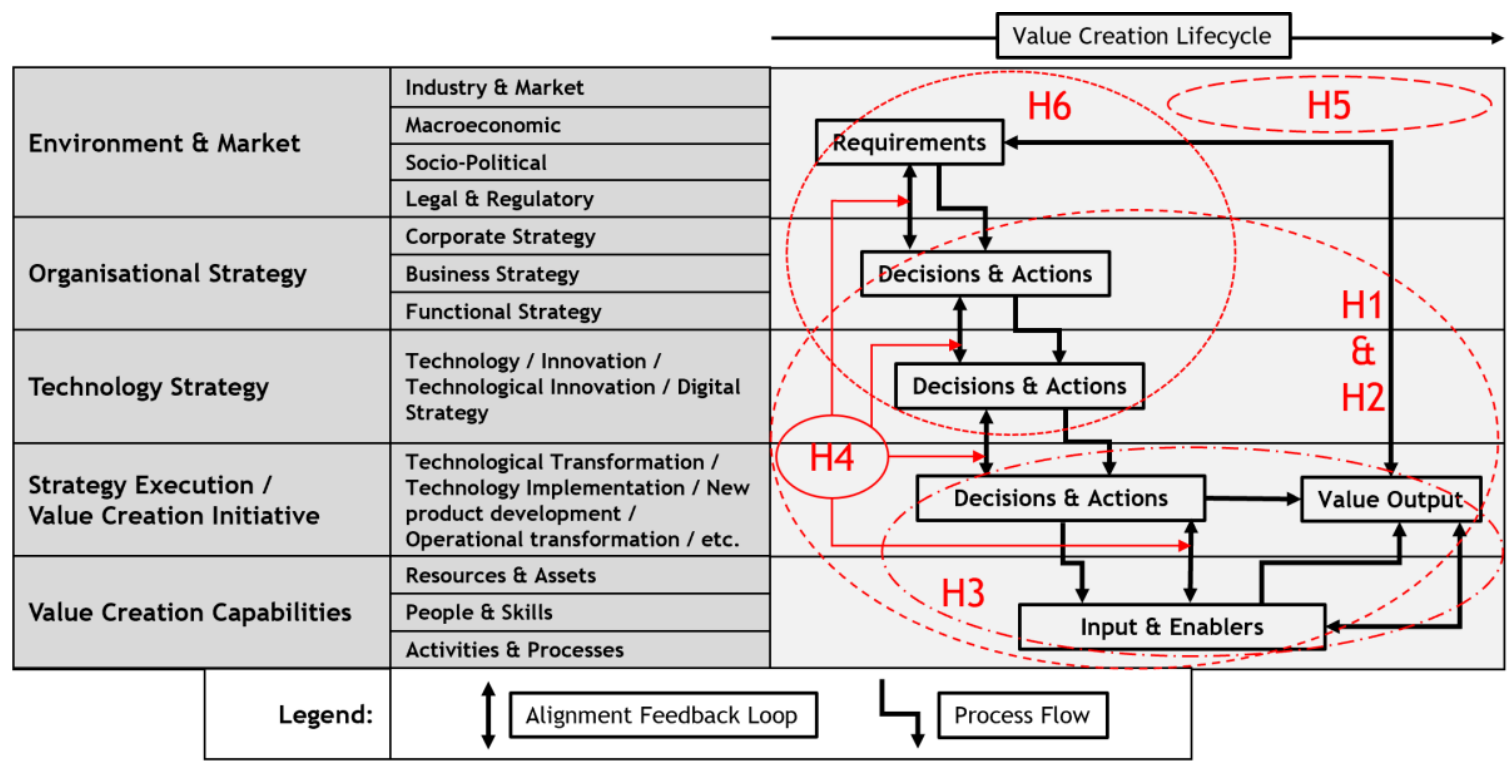

Figure 7: Conceptual Research Model

Table 2: Hypotheses

\begin{tabular}{|l|l|}
\hline Hypothesis no. & Hypothesis \\
\hline H1 & $\begin{array}{l}\text { Technology and innovation play a central role in current value-creation } \\
\text { initiatives, and will become more important and central to enable value } \\
\text { creation in future. }\end{array}$ \\
\hline H2 & $\begin{array}{l}\text { The current major emerging technology initiatives in South African industries } \\
\text { largely focus on digital technologies. }\end{array}$ \\
\hline H3 & $\begin{array}{l}\text { The major challenges that organisations face with creating new value through } \\
\text { emerging technology initiatives largely stem from the difficulty of dynamically } \\
\text { creating, adapting, and managing the required value-creation capabilities to } \\
\text { enable the technology initiative. }\end{array}$ \\
\hline H4 & $\begin{array}{l}\text { Another major challenge stems from the difficulty of dynamically maintaining } \\
\text { strategic alignment throughout the value-creation lifecycle. }\end{array}$ \\
\hline H5 & $\begin{array}{l}\text { These challenges are representative of typical South African industries, although } \\
\text { some may face higher levels of pronounced challenges in different areas. }\end{array}$ \\
\hline H6 & $\begin{array}{l}\text { Emerging technology initiatives bring greater challenges to organisations in their } \\
\text { value-creation initiatives, due to the higher levels of complexity associated with } \\
\text { these technologies. }\end{array}$ \\
\hline
\end{tabular}

\subsection{Research design and method}

This study took an inductive research approach in order to answer the main research question, with the aim of obtaining improved insight into and understanding of a problem area to support the development of further research propositions [102]. This phase was executed through an exploratory research design, using qualitative interviews, to clarify and obtain the required insight and understanding to define clearly the subsequent research problem to pursue in the next research phase [103].

Twelve semi-structured interviews with predefined questions (listed in Table 3 in relation to the hypotheses they aim to validate) were conducted with experts from the three largest technology consulting firms operating in South Africa. These were global firms that typically rank in the top five consulting firms globally (in revenue or performance) that consult in the fields of strategy, management, operations, and 
technology. The interviewees from these firms were experts consulting in the field of technology-enabled value creation, working across strategy and operations, although they were primarily focused on either strategy (six interviewees) or operations (six interviewees). Each of them had experience in emerging and disruptive technology implementation or transformation initiatives to create business and/or stakeholder value for their clients. Furthermore, each had insights into implementing or transforming their own internal business and value-creation processes through similar current emerging technology trends. Although these interviewees worked in the South African branches of these international firms, it should be noted that they work closely with their international counterparts, and so could contrast their perspectives on South African companies and industries with their global perspective.

Table 3: Interview questions

\begin{tabular}{|l|l|l|}
\hline $\begin{array}{l}\text { Hypothesis } \\
\text { no. }\end{array}$ & $\begin{array}{l}\text { Interview } \\
\text { question no. }\end{array}$ & Interview question \\
\hline & 1 & $\begin{array}{l}\text { What is the current role (i.e., central or supporting) and importance } \\
\text { of technology and innovation (i.e., new value) in creating value } \\
\text { in/for organisations? }\end{array}$ \\
\cline { 2 - 3 } & 2 & $\begin{array}{l}\text { How is this role expected to change in future in the changing } \\
\text { technological environment as we progress into the FIR? }\end{array}$ \\
\hline 2 & 3 & $\begin{array}{l}\text { What are the major types of emerging technology implementation } \\
\text { and transformation initiatives taking place in South African } \\
\text { industries that relate to the FIR? }\end{array}$ \\
\hline $3 \& 4$ & 4 & $\begin{array}{l}\text { What are the major challenges faced by organisations across } \\
\text { industries in South Africa, and by the consulting firms themselves, in } \\
\text { creating value that is enabled by emerging technologies? }\end{array}$ \\
\hline 5 & 5 & $\begin{array}{l}\text { Do these challenges differ across industries? } \\
\text { Do these challenges differ between more mature versus more } \\
\text { emerging technologies? }\end{array}$ \\
\hline 6 & 6 &
\end{tabular}

\subsection{Qualitative analysis}

The analytic induction technique was used for the data analysis of the qualitative interview outcomes. Johnson [104] defined 'analytic induction' as "the intensive examination of a strategically selected number of cases so as to empirically establish the causes of a specific phenomenon". In an analytic-inductive-led approach to analysing qualitative data, the analysis begins with a less-defined explanation of the phenomenon to be explored that is not derived from existing theory [102]. This is a suitable approach to the FIR environment when clear theoretical links are yet to be established. The explanation (or proposition) is then tested through a purposefully selected case study, which may be conducted through in-depth interviews that would allow the phenomenon to be explored. The inductive and incremental way of collecting and analysing qualitative data provides this process with the ability to lead to the development of well-grounded explanations [102].

The qualitative interview data obtained from the interviews were first transcribed from the recordings, then cleaned and summarised (condensed) before categorising (grouping) the condensed data into themes, as described by Saunders, Lewis \& Thornhill [102]. Some of the interview questions were closed-ended, while others were open-ended. For the closed-ended questions, the number of responses was counted for each answer category to derive a quantitative representation of the qualitative data [102]. Open-ended responses were also recorded and analysed as noted above, in which interviewees discussed the intended closed-ended questions in more detail. The categorisation enabled the derivation of insights and the identification of patterns from the interviewee responses, as discussed under the results section. The responses that related to each category (or theme) per question were counted to derive a quantitative representation of interviewee perspectives.

\section{$4 \quad$ RESULTS AND DISCUSSION}

\subsection{Outcomes}

The outcomes for the derived categories of the qualitative interviews are discussed in this section for each interview question. A figure is shown for each question, indicating the derived categories from the responses and the quantitative number of responses for each category out of the total of twelve interviewees. The results for Question 4 yielded two distinct categories, which are discussed separately with a figure for each category indicating the total number of responses that correlate with the specific category. 


\subsubsection{Question 1 outcomes}

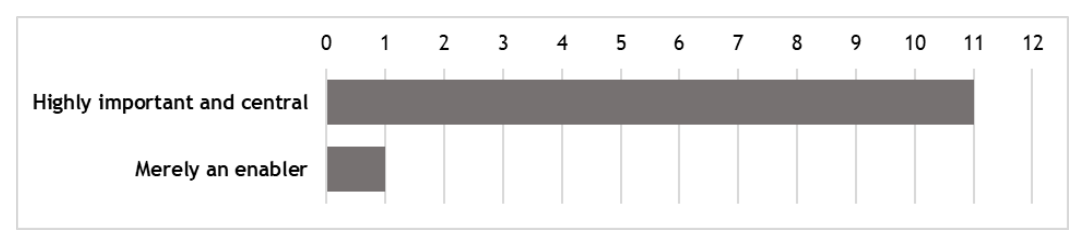

Figure 8: Q1 - Qualitative representation per response category

Eleven out of twelve interviewees agreed that technology is central to value creation and can no longer be seen as having only a supportive role in the current dynamic environment. One interviewee perceived technology to merely be an enabler of (supporting) value creation, which does not necessarily make it central- although this statement depended on the type of value to be created and its complexity.

\subsubsection{Question 2 outcomes}

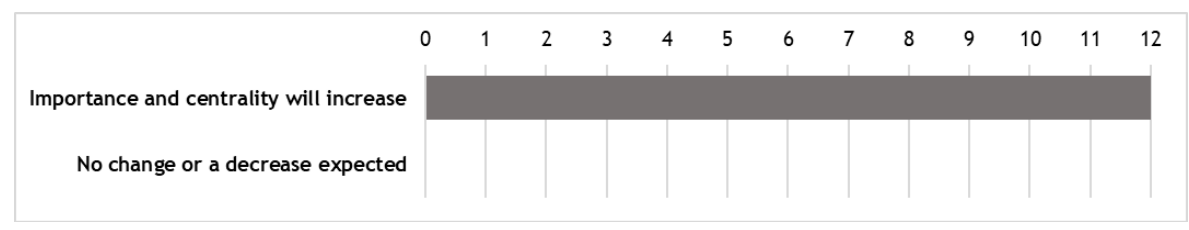

Figure 9: Q2 - Qualitative representation per response category

All interviewees expect technology to become more central to value-creation initiatives, and the prevalence and importance of both technology and innovation is expected to increase, particularly in the FIR.

\subsubsection{Question 3 outcomes}

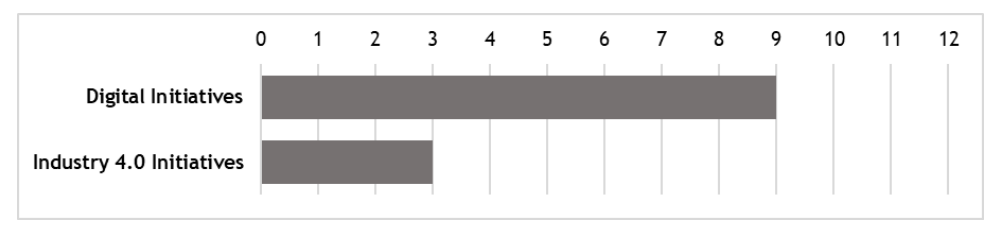

Figure 10: Q3 - Qualitative representation per response category

From the responses on the type of emerging and disruptive technology initiatives taking place in South Africa and in the organisation's global network, it was found that two main categories can be defined. These include digital (with project examples spanning across digital transformations, digital strategies, digitalisation of processes, advanced and/or predictive analytics, Al and machine learning, process automation, digital platform business models, and more) and Industry 4.0 (as the term for cyber-physical integration, or digital and physical emerging technology integrations to deliver technology capabilities for project examples provided, such as smart factories, smart cities, advanced robotisation, system automation, digital twins, integration of complex technology systems, drones with analytics capabilities, and other examples). Nine respondents were primarily involved in digital initiatives. The remaining three were primarily involved in Industry 4.0 (cyber-physical) type initiatives, but were also (or have been) involved in digital initiatives.

\subsubsection{Question 4 outcomes}

The reported challenges to technology enabled value creation in the current business and technology landscape spanned across various organisational levels. Each interviewee discussed the major challenges applicable to their focus area. These challenges could be grouped into two categories: capability-related challenges (Figure 11) and strategic-alignment-related challenges (Figure 12), with twelve and eleven interviewees reporting on each category respectively.

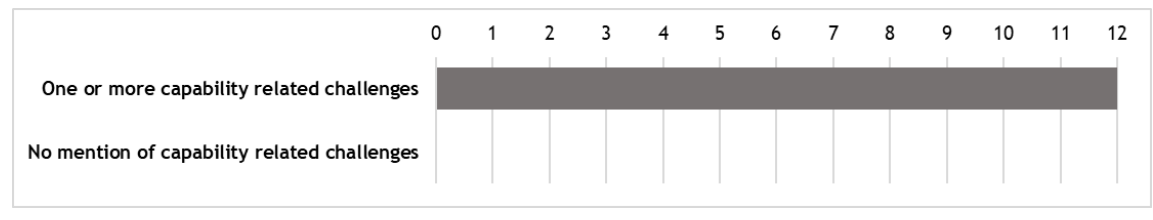

Figure 11: Q4A - Qualitative representation per response category 
The reported challenges associated with capabilities spanned all the organisational levels (i.e., across the hierarchies in a value-creation system) and phases of the value-creation lifecycle. These included the capability elements of people and skills, resources and assets (including technology and other infrastructure and systems), and processes and activities (including procedures, methodologies, know-how, etc.).

Examples of capability-related challenges reported during the interviews (i.e., capability elements required for decision-making and action during the value-creation process) included:

- Identifying and deciding which strategic technologies (resources/assets) to focus on;

- Accurately assessing the potential value and disruption potential of emerging (still-maturing) technologies;

- Taking multiple factors into account when assessing complex requirements that impact the valuecreation initiative;

- Matching technologies to business needs and prioritising focus areas;

- Taking a business-led value-creation focus and identifying enabling technologies as opposed to attempting to 'plug in' new technologies;

- Balancing market/ value-pull versus technology-push approaches to find new value-creation initiatives as a result of new technology capability;

- Managing bottom-up versus top-down approaches in a dynamic environment;

- Identifying, creating, and modifying the capabilities (resources, processes, and/or skills) needed by a new technology initiative;

- Executing and delivering on technology solutions to create the expected value, due to the difficulty associated with building and modifying capabilities to keep up with dynamic trends;

- Strategically managing the value-creation process, including developing organisational and technology strategies, executing strategies, and monitoring and controlling the execution to maintain alignment while adapting as needed;

- $\quad$ Taking a systems approach and identifying the necessary system elements to consider per initiative;

- Managing stakeholder expectations and resistance to change largely based on a 'sunk cost' mindset relating to the legacy systems and infrastructure;

- Managing change and adoption requirements;

- Managing and transferring the necessary knowledge to create the required value and/or to implement the technology capabilities;

- Monitoring and controlling value-creation efforts to align with strategic goals while also adapting dynamically as needed;

- Integrating new and old technology infrastructure and systems;

- Assessing the actual value created and assigning it correctly throughout the organisation and throughout the strategic management hierarchy; and,

- Identifying and adapting the processes, methods, and tools used for decision-making to suit the dynamic value-creation needs for which they are to be deployed (e.g., moving to Agile methods and integrating such a process change coherently into the existing capabilities). Nine respondents noted such challenges with identifying, selecting, adapting, and/or implementing the required methods and tools for decision-making and action.

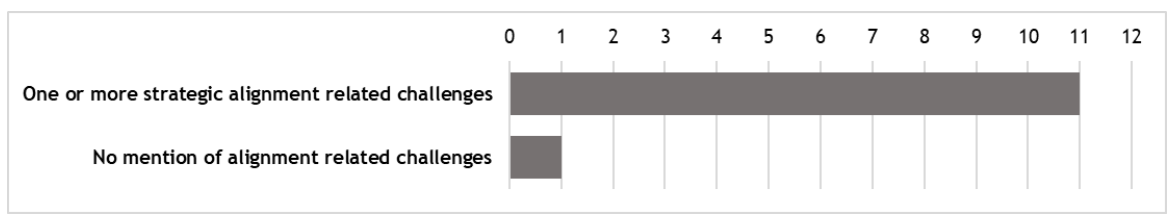

Figure 12: Q4B - Qualitative representation per response category

The reported examples of challenges that related to alignment (or fit) matched the definition for strategic alignment provided earlier. These included:

- Achieving and maintaining alignment between the external market, environmental trends, and the development of the organisation's strategy/ies;

- Achieving and maintaining alignment between business/corporate/organisational strategies and technology/technological innovation strategies;

- Achieving and maintaining alignment between the developed strategy and its execution (implementation or transformation initiative); 
- Achieving and maintaining alignment between various strategy execution efforts to create the desired value;

- Achieving and maintaining alignment between these initiatives, while experiencing shortened and more dynamic lifecycles and strategic timelines;

- Achieving and maintaining alignment between various organisational functions and/or project teams (i.e., reducing 'silo' work); and,

- Creating new and modifying existing capabilities to align with new technology initiatives and dynamic changes in the environment (including, but not limited to, specific aspects such as modifying resources and infrastructure, upskilling employees, adapting processes, and adopting new methodologies, etc.).

\subsubsection{Question 5 outcomes}

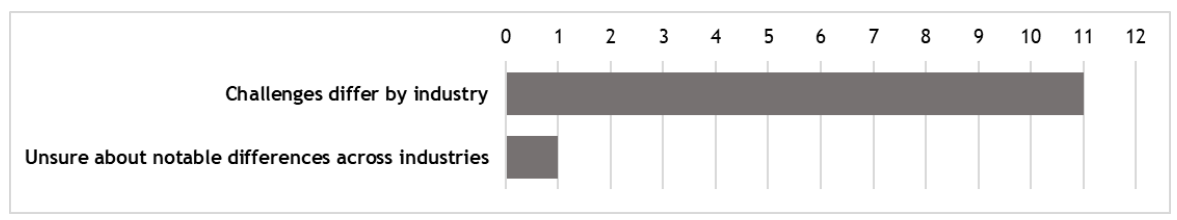

Figure 13: Q5 - Qualitative representation per response category

Eleven of the twelve interviewees noted that the reported challenges differed somewhat between industries, although there was a lot of overlap. The differences were stated to relate to the dominant culture and resistance to change (readiness levels to adopt emerging technologies) in the senior management of the larger organisations in the various industries. Another primary reason that was reported related to the prevalent capabilities to support or enable emerging technology implementations or transformations and the organisation's ability to dynamically adapt these capabilities. One interviewee was uncertain whether there were notable differences between industries, and noted that all seemed to struggle with the same core problems of alignment and developing and executing coherent strategies.

\subsubsection{Question 6 outcomes}

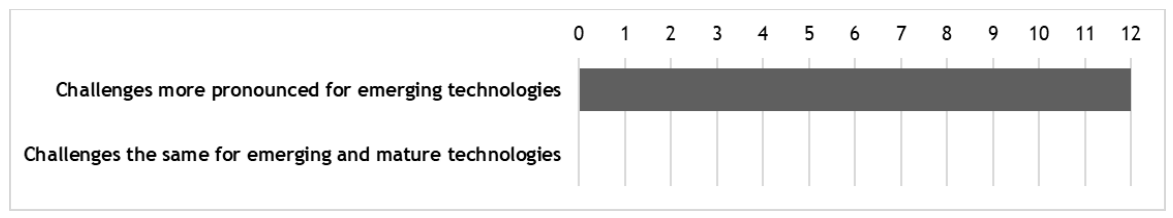

Figure 14: Q6 - Qualitative representation per response category

All twelve interviewees indicated that the reported challenges are more complex, dynamic, and profound when the technology initiatives involve emerging and/or disruptive technologies rather than more mature technologies. The identified correlating factor was the scale of complexity - i.e., the higher the complexity of the technology initiative (in terms of scale, scope, system interfaces and implications, etc.), the more pronounced the challenges of creating value from the initiative.

\subsection{Discussion of findings}

The results are discussed below in line with each of the hypotheses stated in Section 3.

\subsubsection{Hypothesis 1}

Hyphothesis 1 was proven to be correct, with eleven out of twelve interviewees agreeing that technology and innovation are central to value-creation initiatives, and all interviewees agreeing that technology and innovation will only become more central to value-creation initiatives in future, particularly as the FIR unfolds. This highlights the importance of technology-enabled capabilities for organisational value-creation initiatives. It also highlights the growing importance of taking a capability perspective, particularly on technology and innovation capabilities, of an organisation's value-creation system.

\subsubsection{Hypothesis 2}

Hypothesis 2 was proven to be correct, with all interviewees indicating their involvement in emerging technology initiatives relating to the digital technology sphere, and only three indicating involvement in Industry 4.0 (cyber-physical) technology initiatives. This highlights the fact that South African industries are actively involved in emerging technology implementations or transformations. The interviews also indicated that these initiatives aim to alter their value-creation systems in some way through emerging technologies, in order to create some form of value that addresses business goals or stakeholder needs. However, these largely focus on digital initiatives - i.e., increased data and computation initiatives to 
enable value-creation efforts - and not FIR-specific initiatives (integrating digital and biological technology spheres with the digital sphere).

\subsubsection{Hypothesis 3}

Hypothesis 3 was partly proven to be correct, since all interviewees noted that the major challenges to value creation stem in some form from dynamic changes and the resulting complexity of some or multiple capability-related factors. These capability factors related largely to creating, adapting, or managing the associated people, abilities, skills, knowledge, processes, and activities required to make decisions and take action in the value-creation process or system. Apart from challenges with system integration, few of the reported challenges mentioned the actual technical aspects, such as the resources and assets (e.g., technology systems, infrastructure, software) other than referring to the abilities and tools required for technology, systems, trend, or other assessments.

What is clear, however, is that Hypothesis 3 considered the capability-related challenges to be largely concentrated on the strategy execution level (see Figure 7). These included the capabilities necessary for executing a value-creation initiative to achieve the strategic objectives. However, the interview results indicated that the challenges that stem from dynamic capabilities span all the hierarchies of the valuecreation system. In fact, based on the interview results, the conceptual model in Figure 6 can be expanded by accounting for a third dimension to represent the strategic management activities involved in dynamically creating, adapting, and managing the capability elements throughout the value-creation system of an organisation. This conceptual model is shown in Figure 15.

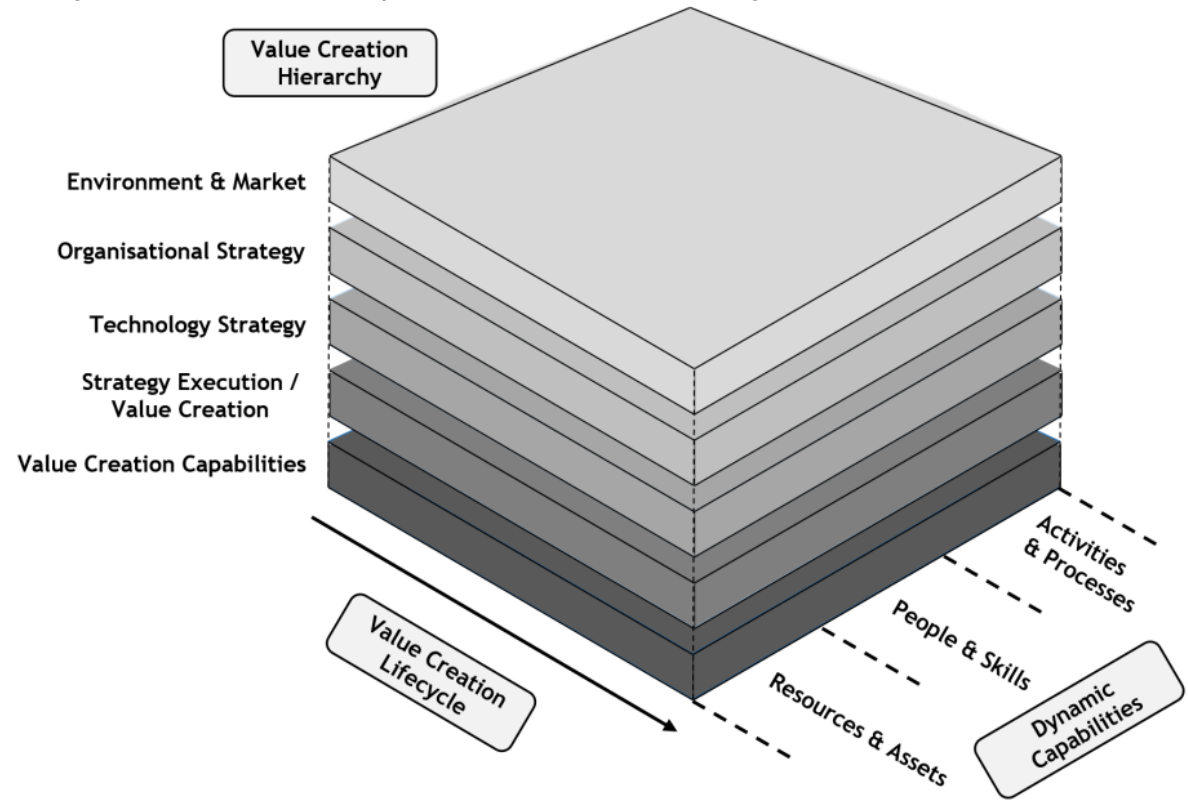

Figure 15: Conceptual model for the strategic management of technology-enabled value creation

\subsubsection{Hypothesis 4}

Hypothesis 4 was proven to be correct, with numerous challenges to achieving and maintaining alignment on various hierarchical levels being noted. Since strategic alignment requires alignment across all the levels noted in Section 2.4, any misalignment will have a detrimental effect on value-creation efforts, as confirmed by the interviews. The added dimension to the conceptual model in Figure 15 also represents the dynamic capabilities (i.e., the dynamic capacities and constituent activities) approach needed to achieve and maintain strategic alignment throughout the value-creation hierarchies and lifecycle.

\subsubsection{Hypothesis 5}

Hypothesis 5 was partly proven to be correct, in that all industries experience the identified challenges in some form or another. However, it was noted that the degree of the challenges differs between industries.

\subsubsection{Hypothesis 6}

Hypothesis 6 was proven to be correct, since all respondents indicated that the technology initiatives that they were involved in were significantly more complex, and faced greater challenges when emerging technologies were involved. 
In this study it was found that the major challenges faced by organisations in creating technology-enabled value in the FIR can be attributed to the difficulty of dynamically creating, adapting, and managing the underlying capabilities that are needed. These trends in the challenges experienced by organisations were identified by categorising the challenges reported by the interviewees from a cross-industry perspective. These trends in the challenges faced in creating technology-enabled value in the FIR correlate with the dynamic capabilities theory and perspective on strategic management, and with the research on strategic alignment. This encompasses the difficulty of adapting capabilities to address dynamic changes, and of maintaining strategic alignment throughout an organisation's value-creation system while doing so. A conceptual model was presented for the purpose of illustrating a dynamic capabilities perspective in relation to an organisation's value-creation system and the lifecycle of related initiatives.

Recommendations for future research include the development of a working model to support the strategic management of technology-enabled value creation in the FIR, and the validation of such a model in practice to determine its applicability to supporting strategic alignment in FIR environments. Future research is also recommended to explore these identified trends in the major challenges faced by organisations, and their pervasiveness across industries and in differently sized organisations.

The validation of Hypothesis 2, based on the expert interviews, indicates a current trend of placing a greater emphasis on digital technologies and initiatives. This seems to indicate that South Africa focuses more strongly on the continual expansion of the Third Industrial Revolution (TIR) than on the new initiatives of the FIR (consisting of the digital, physical, and biological technology spheres [10]) or of Industry 4.0 (consisting of the digital/cyber and physical technology spheres [109]). This may be attributed to the largescale pervasiveness of digital technologies in most emerging technology trends; or it may be attributed to a lack of other technology focus areas in South Africa. Future research on the degree to which South African industries are pursuing FIR initiatives and technology capability development as compared to expanding TIR technology initiatives and capabilities is recommended. It would be interesting to explore the pervasiveness of these Digital trends in the various local industries as well as between differently sized organisations.

\section{REFERENCES}

[1] Phaal, R., O’Sullivan, E., Routley, M., Ford, S. \& Probert, D. 2011. A framework for mapping industrial emergence. Technological Forecasting \& Social Change, 78(2011), 217-230.

[2] Gius, D., Mieszala, J., Panayioutou, E. \& Poppensieker, T. 2018. Value and resilience through better risk management. McKinsey \& Company: Risk Article. [Online] available at: https://www.mckinsey.com/businessfunctions/risk/our-insights/value-and-resilience-through-better-risk-management [Accessed 12 February 2019].

[3] Phaal, R., Farrukh, C.J.P. \& Probert, D.R. 2001. A framework for supporting the management of technological innovation. Eindhoven Centre for Innovation Studies - Conference, "The future of innovation studies", Eindhoven University of Technology, the Netherlands, 20-23 September 2001.

[4] Vojak, B.A. \& Chambers, F.A. 2004. Roadmapping disruptive technical threats and opportunities in complex, technology-based subsystems: The SAILS methodology. Technological Forecasting \& Social Change, 71, 121-139.

[5] Saritas, O. \& Oner, M.A. 2004. Systemic analysis of UK Foresight results: Joint application of integrated management model and roadmapping. Technological Forecasting \& Social Change, 71(1), 27-65.

[6] Christensen, C.M. 1997. The innovator's dilemma: When new technologies cause great firms to fail. Boston, MA: Harvard Business School Press.

[7] Christensen, C.M. 2006. The ongoing process of building a theory of disruption. J. Prod. Innov. Manag., 23(1), 3955.

[8] Teece, D.J. 2007. Explicating dynamic capabilities: The nature and micro foundations of (sustainable) enterprise performance. Strateg. Manag. J., 28(13), 1319-1350.

[9] Cheng, Y., Huang, L., Ramlogan, R. \& Li, X. 2017. Forecasting of potential impacts of disruptive technology in promising technological areas: Elaborating the SIRS epidemic model in RFID technology. Technological Forecasting \& Social Change, 117(2017), 170-183.

[10] Schwab, K. 2016. The Fourth Industrial Revolution. World Economic Forum: Geneva (Switzerland). New York: Crown Business.

[11] Daemmrich, A. 2017. Invention, innovation systems, and the fourth industrial revolution. National Academy of Inventors, Technology and Innovation, 18, 257-265.

[12] Harris Aslam, M.M \& Azhar, S.M. 2013. Globalisation and development: Challenges for developing countries. International Journal of Economic Policy in Emerging Economies, 6(2), 158-167.

[13] Spath, D., Ganschar, O., Gerlach, S., Hämmerle, M., Krause, T. \& Schlund, S. 2013. Produktionsarbeit der Zukunft: Industrie 4.0. Stuttgart: Fraunhofer.

[14] Bauernhansl, T., Schatz, A. \& Jäger, J. 2014. Komplexität bewirtschaften: Industrie 4.0 und die folgen: Neue herausforderungen für sozio-technische produktionssysteme. Zeitschrift für Wirtschaftlichen Fabrikbetrieb, 109(5), 347-350. 
[15] Hirsch-Kreinsen, H. \& Weyer, J. 2014. Wandel von produktionsarbeit: “Industrie 4.0”. Working paper, Technical University of Dortmund.

[16] Joyce, A. \& Paquin, R.L. 2016. The triple layered business model canvas: A tool to design more sustainable business models. Journal of Cleaner Production, 135(2016), 1474-1486.

[17] Amadi-Echendu, J., Lephauhau O., Maswanganyi, M. \& Mkhize, M. 2011. Case studies of technology roadmapping in mining. Journal of Engineering and Technology Management, 28(2011), 23-32.

[18] Schilling, M.A. 2013. Strategic management of technological innovation, $4^{\text {th }}$ ed. New York: McGraw-Hill Education.

[19] Bicak, M. 2019. What artificial intelligence means for the future of work. Business Reporter Article. [Online] available at: https://www.business-reporter.co.uk/2019/01/28/what-artificial-intelligence-meansfor-the-future-of-work/\#gsc.tab=0 [Accessed 22 August 2019].

[20] Bender, M., Henke, N. \& Lamarre, E. 2018. The cornerstones of large technology transformation. McKinsey \& Company: Digital McKinsey Article. [Online] available at: https://www.mckinsey.com/businessfunctions/mckinsey-digital/our-insights/the-cornerstones-of-large-scale-technology-transformation [Accessed 02 May 2019].

[21] Rose, G. 2016. The fourth industrial revolution: A Davos reader. Washington, DC: Council on Foreign Relations.

[22] Kurzweil, R. 2005. The singularity is near: When humans transcend biology. London: Penguin.

[23] Kelly, K. 2016. The inevitable: Understanding the 12 technological forces that will shape our future. New York: Viking Press.

[24] White, M.A. \& Bruton, G.D. 2011. The management of technology and innovation: A strategic approach, $2^{\text {nd }}$ edition. Mason: South-Western Cengage Learning.

[25] Schwieters, N. 2016. The future of industries: Bringing down the walls. PWC's Future in insight series. [Online] Available at: https://www.pwc.com/gx/en/industries/industrial-manufacturing/publications/pwccips-future-of-industries.pdf. [Accessed 16 April 2019].

[26] Atluri, V., Dietz, M. \& Henke, N. 2017. Competing in a world of sectors without borders. McKinsey Quarterly article. [Online] available at: https://www.mckinsey.com/business-functions/mckinsey-analytics/ourinsights/competing-in-a-world-of-sectors-without-borders [Accessed 18 April 2019].

[27] Walden, D.D., Roedler, G.J., Forsberg, K.J., Hamelin, R.D. \& Shortell, T.M. 2015. System engineering handbook: $A$ guide for system life cycle process and activities $4^{\text {th }}$ edition. San Diego: International Council on Systems Engineering (INCOSE).

[28] Bauer, W., Schlund, S., Marrenbach, D. \& Ganschar, O. 2014. Industrie 4.0: Volkswirtschaftliches potenzial für Deutschland. Berlin, Stuttgart: BITKOM, Fraunhofer IAO.

[29] Bauernhansl, T., ten Hompel, M. \& Vogel-Heuser, B. 2014. Industrie 4.0: Anstoß, vision, vorgehen. In Industrie 4.0 in produktion, automatisierung und logistik: Anwendung, technologien, migration, pp. 625-634. Wiesbaden: Springer.

[30] Sahlman, K. 2010. Elements of strategic technology management. Dissertation, PhD Eng. Faculty of Technology, Department of Industrial Engineering and Management, University of Oulu.

[31] Brabham, D.C. 2015. Crowdsourcing in the public sector. Washington, DC: Georgetown University Press.

[32] Teece, D., Pisano G. \& Shuen, A. 1997. Dynamic capabilities and strategic management. Strategic Management Journal, 18(7), 509-533.

[33] Inan, G.G. \& Bititci, U.S. 2015. Understanding organizational capabilities and dynamic capabilities in the context of micro enterprises: A research agenda. Procedia - Social and Behavioral Sciences, 210, 310-319.

[34] Pisano, G.P. 2017. Towards a prescriptive theory of dynamic capabilities: Connecting strategic choice, learning, and competition. Industrial and Corporate Change, 26(5), 747-762.

[35] Shahid, Y. 2001. Globalization and the challenge for developing countries. Policy Research Working Paper, No. 2618. Washington, DC: World Bank. [Online] Available at: https: //openknowledge.worldbank.org/handle/10986/19631 [Accessed 12 January 2020]. License: CC BY 3.0 IGO.

[36] Kruger, N. 2016. South Africa has a skills shortage: How do we fix it? World Economic Forum Article. [Online] available at:

https://www.weforum.org/agenda/2016/05/south-africa-skills-shortage-how-do-we-fix-it/ [Accessed 15 February 2020].

[37] United Nations. 2014. World economic situation and prospects 2014. New York: United Nations Publication.

[38] Baier, K. 1966. What is value? An analysis of the concept. Researcher (eds), Values and the future: The impact of technological change on American values. New York: The Free Press, pp. 33-67.

[39] Haksever, C., Chaganti, R. \& Cook, R.G. 2004. A model of value creation: Strategic view. Journal of Business Ethics, 49, 291-305.

[40] Ansoff, I. 1979. Strategic management. London: McMillan.

[41] Teece, D.J. 2014. The foundations of enterprise performance: Dynamic and ordinary capabilities in an (economic) theory of firms. Academy of Management Perspectives, 28(4), 328-352.

[42] Romanowska, E. 2001. Relationships between core competence, skills and capabilities: A consistent hierarchical framework to clarify terminology. Collaborative white paper between the Council for Scientific and Industrial Research and the University of Pretoria, South Africa.

[43] Cetindamar, D., Phaal, R. \& Probert, D. 2009. Understanding technology management as a dynamic capability: A framework for technology management activities. Technovation, 29(4), 237-246.

[44] Winter, S. 2003. Understanding dynamic capabilities. Strategic Management Journal, 24(10), 991-995.

[45] Helfat, C.E. 1997. Know-how and asset complementarity and dynamic capability accumulation. Strategic Management Journal, 18(5), 339-360. 
[46] O Regan, N. \& Ghobadian A. 2004. The importance of capabilities for strategic direction and performance. Management Decision, 42(2), 292-312.

[47] Davey, S. 1998. Managing competencies in businesses with high intellectual capital gearing. $8^{\text {th }}$ International Forum on Technology Management, November 1998.

[48] Prahalad, C.K. \& Hamel, G. 1990. The core competence of the corporation. Harvard Bus. Rev. [Online] Available at:

http://www.cfmt.it/sites/default/files/af/materiali/The_Core_Competence_of_the_Corporation.pd f [Accessed 03 October 2019]

[49] Javidan, M. 1998. Core competence: What does it mean in practice? Long Range Planning, 31(1), 60-71.

[50] Christensen, C.M. 2019. After 25 years studying innovation, here is what I have learned. Linkedln post. [Online] Available at:

https: / /www.linkedin.com/pulse/after-40-years-studying-innovation-here-what-i-have-christensen/. [Accessed 12 August 2019].

[51] Hobday, M. 2005. Firm-level innovation models: Perspectives on research in developed and developing countries. Technology Analysis \& Strategic Management, 17(2), 121-146.

[52] Burgelman, R.A., Maidique, M.A. \& Wheelwright, S.C. 2001. Strategic management of technology and innovation. New York: McGraw-Hill.

[53] Mahmood, Z., Amir, A., Javied, S. \& Zafar, D. 2013. Strategic management of technology and innovation. Global Journal of Management and Business Research Administration and Management, 13(12). [Online] Available at: https://journalofbusiness.org/index.php/GJMBR/article/view/1122 [Accessed 04 June 2019].

[54] Lahovnik, M. \& Breznik, L. 2013. Innovation management and technological capabilities as a source of competitive advantage. In Active Citizenship by Knowledge Management \& Innovation: Proceedings of the Management, Knowledge and Learning International Conference 2013. ToKnowPress. [Online] Available at: https: //ideas.repec.org/h/tkp/mklp13/771-779.html [Accessed 12 July 2019].

[55] McCarthy, I.P. 2003. Technology management: A complex adaptive systems approach. Int. J. Technology Management, 25(8), 728-745.

[56] Phaal, R., Farrukh, C.J.P. \& Probert, D.R. 2004. Technology roadmapping: A planning framework for evolution and revolution. Technological Forecasting \& Social Change, 71(2004), 5-26.

[57] Desouza, K.C. 2005. New frontiers of knowledge management. London: Palgrave Macmillan.

[58] Du Toit, J. 2007. Managing discontinuous change. iPlan Industrial Engineers, White Paper. [Online] Available at: http://iplan.global/Downloads/du\%20Toit\%20-\%20Managing\%20discontinuous\%20change.pdf [Accessed 17 May 2019].

[59] De Wet, G. 2001. Technology space maps for technology management and audits. Pretoria: Faculty of Engineering, University of Pretoria.

[60] Andrews, K. 1971. The concept of corporate strategy. Homewood: Irwin.

[61] Teece, D. \& Pisano, G. 1994. The dynamic capabilities of firms: An introduction. Industrial and Corporate Change, 3(3), 537-556.

[62] Eisenhardt, K. \& Martin, J. 2000. Dynamic capabilities: What are they? Strategic Management Journal, 21(10-11), 1105-1121.

[63] Helfat, C.E., Finkelstein, S., Mitchell, W., Peteraf, M., Singh, H. \& Teece, D. 2007. Dynamic capabilities: Understanding strategic change in organisations. New Jersey: Wiley-Blackwell.

[64] Teece, D.J. 2018. Dynamic capabilities. David J. Teece - The scholar entrepreneur. [Online] Available at: https://www.davidjteece.com/dynamic-capabilities [Accessed 07 July 2019].

[65] Certo, S.M., Peter, J.P. \& Ottensmeyer, E. 1995. The strategic management process. $3^{\text {rd }}$ edition. Homewood: Austen Press.

[66] Luftman, J.N. \& Brier, T. 1999. Achieving and sustaining business-IT alignment. Calif. Manage. Rev., 42(1), 109122.

[67] Reich, B.H. \& Benbasat, I. 2000. Factors that influence the social dimension of alignment between business and information technology objectives. MIS Quart., 24(1), 81-113.

[68] Palmer, J.W. \& Markus, M.L. 2000. The performance impacts of quick response and strategic alignment in specialty retailing. Information Systems Research, 11(3), p. 242.

[69] Henderson, J.C. \& Venkatraman, N. 1993. Strategic alignment: Leveraging information technology for transforming organizations. IBM Systems Journal, 32(1), 4-16.

[70] Alyahya, M. \& Suhaimi, M.A. 2013. A conceptual model for business and information technology strategic alignment from the perspective of small and medium enterprises. International Journal of Business, Humanities and Technology, 3(7).

[71] Bruce, K. 1998. Can you align IT with business strategy? Strategy \& Leadership, 26(5), pp. 16.

[72] Yeow, A. Soh, C. \& Hansen, R. 2018. Aligning with new digital strategy: A dynamic capabilities approach. The Journal of Strategic Information Systems, 27(1), pp. 43-58. [Online] Available at: https://doiorg.uplib.idm.oclc.org/10.1016/j.jsis.2017.09.001 [Accessed on 14 September 2019].

[73] Atmar, H., Becdach, C., Kleinman, S. \& Rieckhoff, K. 2019. Bridging the gap between a company's strategy and operating model. [Online] Available at: https://www.mckinsey.com/business-functions/organization/ourinsights/bridging-the-gap-between-a-companys-strategy-and-operating-model?cid=other-eml-altmip-mck\&hlkid=fe397cd1787c450281b3d9181e5a764e\&hctky=9786459\&hdpid=c7c5db25-887f-4297b3a2-dff6e21657d8 [Accessed 01 June 2019]. 
[74] Probert, D.R., Phaal, R. \& Farrukh, C.J.P. 2003. Technology roadmapping: Linking resources to strategic goals. Paper based on the research project, Strategic technology management: linking technology resources to business objectives, EPSRC project GR/L62900, April 1998-July 2001.

[75] Reich, B.H. \& Benbasat, I. 1996. Measuring the linkage between business and information technology objectives. MIS Quart., 20(1), 55-81.

[76] Chan, Y.E., Sabherwal, R. \& Thatcher, J.B. 2006. Antecedents and outcomes of strategic IS alignment: An empirical investigation. IEEE Transactions on Engineering Management, 53(1), 27-47.

[77] Renaud, A., Walsh, I. \& Kalika, M. 2016. Is SAM still alive? A bibliometric and interpretive mapping of the strategic alignment research field. J. Strat. Inform. Syst., 25(2), 75-103.

[78] Weiss, J. \& Anderson, D. 2004. Aligning technology and business strategy: Issues \& frameworks, A field study of 15 companies. Proceedings of the 37th Hawaii International Conference on System Sciences, Institute of Electrical and Electronics Engineers, 5-8 January 2004.

[79] Baker, J., Jones, D.R., Cao, Q. \& Song, J. 2011. Conceptualizing the dynamic strategic alignment competency. Journal of the Association for Information Systems, 12(4), pp. 299-322.

[80] Chan, Y.E. \& Reich, B.H. 2007. IT alignment: What have we learned? Journal of Information Technology, 22(4), 297-315.

[81] Reynolds, P. \& Yetton, P. 2015. Aligning business and IT strategies in multi-business organizations. J. Inform. Technol., 30(2), 101-118.

[82] Pearce, J.A. II \& Robinson, R.B. 2011. Strategic management: Formulation, implementation, and control, 12 ed. New York: McGraw Hill International.

[83] Kagermann, H., Wahlster, W. \& Helbig, J. 2013. Recommendations for implementing the strategic initiative Industrie 4.0: Final report of the Industrie 4.0 Working Group. Frankfurt am Main: Communication Promoters Group of the Industry-Science Research Alliance.

[84] Lasi, H., Fettke, P., Kemper, H.-G., Feld, T. \& Hoffmann, M. 2014. Industry 4.0. Business \& Information Systems Engineering, 6(4), 239-242.

[85] Coltman, R., Tallon, P., Sharma, R. \& Queiroz, M. 2015. Strategic IT alignment: Twenty-five years on. J. Inform. Technol., 30(2), 91-100.

[86] Bharadwaj, A., Sawy, O.A., Pavlou, P.A. \& Venkatraman, N. 2013. Digital business strategy: Toward a next generation of insights. MIS Quart., 37(2), 471-482.

[87] El Sawy, O.A. 2003. The IS core IX: The 3 faces of IS identity: Connection, immersion, and fusion. Communications of the Association for Information Systems, 12(1), 588-598.

[88] Pillkahn, U. 2008. Using trends and scenarios as tools for strategy development: Shaping the future of your enterprise. Erlangen, Publicis Corporate Publishing, 80-104.

[89] Walsh, S. 2004. Roadmapping a disruptive technology: A case study: The emerging microsystems and top-down nanosystems industry. Technological Forecasting \& Social Change, 71(2004), 161-185.

[90] Sahlman, K. \& Haapasalo, H. 2009. Perceptions of strategic management of technology in small high-tech enterprises. PICMET 2009 Proceedings, August 2-6, Portland, Oregon USA, 93-104.

[91] Whalen, P.J. 2007. Strategic and technology planning on a roadmapping foundation. Research Technology Management, 50(3), 40-51.

[92] Tallon, P.P. 2008. A process-oriented perspective on the alignment of information technology and business strategy. Journal of Management Information Systems, 24(3), 227-268.

[93] Carvalho, M.M., Fleury, A. \& Lopes, A.P. 2013. An overview of the literature on technology roadmapping (TRM): Contributions and trends. Technological Forecasting and Social Change, 80(7), 1418-1437.

[94] Porter, M.E. 1985. Competitive advantage: Creating and sustaining superior performance. New York: The Free Press.

[95] Mei, S. \& Nie, M. 2008. An empirical investigation into the impact of firm's capabilities on competitiveness and performance. International Journal of Management and Enterprise Development, 5(5), 574-589.

[96] Weill, P. \& Broadbent, M. 2002. Building IT infrastructure for strategic agility. Sloan Management Review, 44(10), 57-65.

[97] Karpovsky, A. \& Galliers, R.D. 2015. Aligning in practice: From current cases to a new agenda. J. Inform. Technol., 30(2), 136-160.

[98] Street, C., Gallupe, B. \& Baker, J. 2018. The influence of entrepreneurial action on strategic alignment in new ventures: Searching for the genesis of alignment. Journal of Strategic Information Systems, 27(1), 59-81.

[99] Mithas, S., Tafti, A. \& Mitchell, W. 2013. How a firm's competitive environment and digital strategic posture influence digital business strategy. MIS Quart., 37(2), 511-536.

[100] Marabelli, M. \& Galliers, R.D. 2017. A reflection on information systems strategizing: The role of power and everyday practices. Inform. Syst. J., 27(3), 347-366.

[101] Teece, D.J. 2009. Dynamic capabilities and strategic management: Organizing for innovation and growth. New York: Oxford University Press.

[102] Saunders, M., Lewis, P. \& Thornhill, A. 2009. Research methods for business students, $5^{\text {th }}$ edition. Edinburgh Gate: Pearson Education Limited.

[103] Kotler, P., Adam, S., Brown, L. \& Armstrong, G. 2006. Principles of marketing, $3^{\text {rd }}$ edition. London: Pearson Education.

[104] Johnson, P. 2004. Analytic induction. In C. Cassell and G. Symon (eds), Essential guide to qualitative methods and analysis in organizational research. London: Sage, 165-79.

[105] Rabelo, R.J. \& Bernus, P. 2015. A holistic model of building innovation ecosystems. IFAC-PapersOnLine, 48(3), 2250-2257. 
[106] Du Plessis, M.J. \& Pretorius, M.W. 2017. Towards a better understanding of the key elements driving the innovativeness of the mineral resources industry: A literature review. In 2017 Proceedings of PICMET ' 17 Technology Management for Interconnected World. Portland: Portland International Center for Management of Engineering and Technology.

[107] Talmar, M., Walrave, B., Podoynitsyna, K.S., Holmström, J., \& Romme, A.G.L. 2018. Mapping, analyzing and designing innovation ecosystems: The ecosystem pie model. [Online] Available at: https: //www-sciencedirect-com.uplib.idm.oclc.org/science/article/pii/S0024630118304667 [Accessed 25 July 2019].

[108] Robaczewska, J., Vanhaverbeke, W. \& Lorenz, A. 2019. Applying open innovation strategies in the context of a regional innovation ecosystem: The case of Janssen Pharmaceuticals. Global Transitions, 1(2019), 120-131.

[109] Lee, J., Bagheri, B. \& Kao, H. 2015. A cyber-physical system architecture for Industry 4.0-based manufacturing systems. Manufacturing Letters, 3(2015), 18-23. 